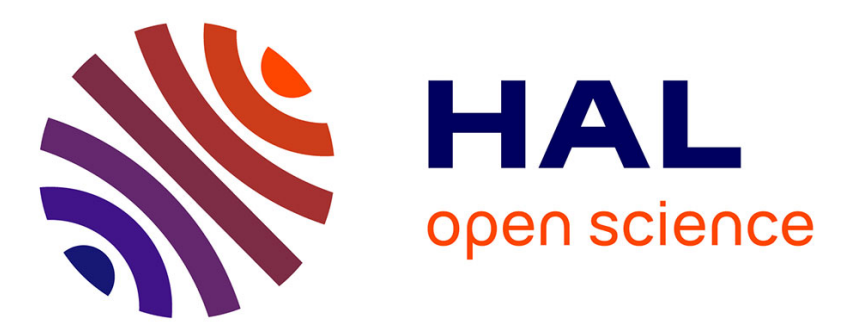

\title{
An Alternative Memory of the Khmer Rouge Genocide: The Dead of the Mass Graves and the Land Guardian Spirits [Neak ta]
}

Anne Yvonne Guillou

\section{- To cite this version:}

Anne Yvonne Guillou. An Alternative Memory of the Khmer Rouge Genocide: The Dead of the Mass Graves and the Land Guardian Spirits [Neak ta]. South East Asia Research, 2012, Life after Collective Death in South East Asia Research: Part 1 - The (Re-)Fabrication of Social Bonds, 20 (2), pp.207-226. 10.5367/sear.2012.0102 . halshs-02553532

\section{HAL Id: halshs-02553532 \\ https://shs.hal.science/halshs-02553532}

Submitted on 24 Apr 2020

HAL is a multi-disciplinary open access archive for the deposit and dissemination of scientific research documents, whether they are published or not. The documents may come from teaching and research institutions in France or abroad, or from public or private research centers.
L'archive ouverte pluridisciplinaire HAL, est destinée au dépôt et à la diffusion de documents scientifiques de niveau recherche, publiés ou non, émanant des établissements d'enseignement et de recherche français ou étrangers, des laboratoires publics ou privés. 
"An alternative memory of the Khmer Rouge genocide :

The dead of the mass graves and the land guardian spirits (neak ta)"

Dr Anne Yvonne Guillou

Anthropologist

Researcher of the French National Centre of Scientific Research (CNRS)

Centre of Southeast Asian Studies (CASE), Paris

South East Asia Research (SOAS, London), 2012, Vol. 20, Issue 2, pp. 193-212.

doi: $10.5367 /$ sear.2012.0102

\section{Introduction}

Wars and revolution violently impacted upon the three countries of what was once French Indochina in the bipolar political and military context of the Cold $\mathrm{War}^{1}$. They were responsible for the massive destruction of infrastructures, social fabric and human lives, bringing deep social suffering and social fracture which are still perceptible. However, little attention has been paid to the way in which individuals perceived this destruction, gave meaning to it, and went through the ordeal of losing their relatives, their work, their property, and - in the case of Cambodia - the very meaning of being Khmer in a country where "Khmer have killed Khmer", as a widely used Cambodian saying puts it. This massive destruction has forced every society affected by it to think about the dialectic of break/continuity in its individual and collective lives ${ }^{2}$. The social memory and meaning of the

\footnotetext{
${ }^{1}$ Anne-Christine Taylor's comments on my research programme gave me new insights which proved to be fruitful in the field. I am indebted to Michel Rethy Antelme and Olivier de Bernon for sharing their knowledge with me on various aspects of my research. An early version of this article was presented at the seminar of the Centre Asie du Sud-Est, Paris in November 2009 and I benefitted from the discussion with my colleagues. Thank you to Bénédicte Brac de la Perrière for her helpful commentaries on this article. I am also deeply grateful to David Chandler for the constructive comments he made on it and his words of encouragement.

This research was funded by the Centre Asie du Sud-Est of the French National Center of Scientific Research (CNRS).

${ }^{2}$ I have shown in another article that women are perceived as the strongest pillars of shattered Cambodian society. It is one of the reasons why prostitution and women's "immoral behaviour" is a big issue in Cambodia. See Anne Y. Guillou (2000), 'Promotion de la femme et sexualité conjugale en temps de sida. Le 'principe de coupure' chez les Cambodgiennes instruites', in Marie-Eve Blanc et Laurence Husson et Evelyne Micollier (eds.), Sociétés Asiatiques face au Sida, L'Harmattan, Paris, pp. 67-91 [Promotion of Women and conjugal Sexuality
} 
massive destruction has evolved at different times and in different groups and does not necessarily follow the political agreements decided by international diplomacy ${ }^{3}$. In this regard, the massive destruction carried out by the Khmer Rouge in Cambodia from 1975 to 1979 is not yet a piece of past history, since the "Khmer Rouge Tribunal" was only set up in recent years, while other forms of social memory have developed, such as commemoration by the Cambodian state, and the more informal peasant practices that I describe in this article.

\section{The context of the research}

The analysis that I present in this article is drawn from a research programme that I initiated in 2006. It aims to analyze the process of social recovery following the social disruptions caused by years of war, genocide and guerrilla warfare between the 1960s and the 1990s, as well as the meaning given to it by Cambodians of various backgrounds. I am trying to build up an "anthropology of traces" that all this violence have left on bodies, psyches, landscapes, and rituals by tracing the language that makes sense for the Cambodian people themselves. The majority of my fieldwork has been undertaken in the province of Pursat (Western Cambodia) in a village that I will call Kompong Trolach ${ }^{4}$ from which I widened my inquiries to two communes in the district of Bakan ${ }^{5}$. When I began my work, I had decided not to ask direct questions about the Khmer Rouge regime and not to use any biographical methods in order to avoid the imposition of such ethical categories as genocide, violence, suffering and trauma. Instead I began my inquiries by asking questions about what seemed to

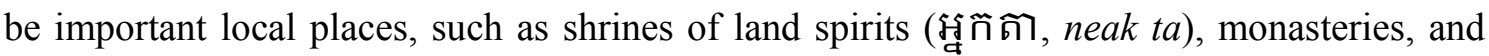

confronted to the AIDS Epidemics].

${ }^{3}$ In his groundbreaking research on the cultural meaning of mass war deaths in Vietnam, Heonik Kwon shows how the Cold War has not been analyzed from the Asian people's point of view, but from that of Westerners, for most of whom the war remained an ideological one rather than a concrete bloody one. Heonik Kwon (2008), Ghosts of War in Vietnam, Cambridge University Press, Cambridge.

${ }^{4}$ The name of the village has been changed in order to respect the anonymity of the people that I have interviewed.

${ }^{5}$ I have selected this area partly because the province of Pursat experienced harsh treatment during the Democratic Kampuchea regime. It is also an area representative of the average Cambodian village, with a subsistence production of paddy cultivated in non irrigated rice fields by Khmer people. Khmer people represent more than ninety percent of the population of Cambodia. 
canals (waterways). I was soon convinced that it made sense in the context of local history dominated by the powerful presence of Grandfather Khleang Mueng, a sixteenth- century Khmer army general who had defeated a Siamese army and was later transformed into a land spirit protecting the area. In other words, I chose the idiom of the places in order to encourage people to talk about their stories. The ethnographic information I gathered made me understand that there were special links among some stones, some trees, some objects, some land spirits, some dead of the Khmer Rouge mass graves, and some human beings. They were related through a circulating energy called $47 \delta$ धิ (from Sanskrit "pāramī, pronounced boromey). This popular religious system has not yet been documented as such, although there are a few publications on separate elements of this system such as Theravadin Buddhist practices $^{6}$ and the worship of various spirits such as neak $t a^{7}$.

Through my description of the treatment of the dead in the Khmer Rouge mass graves and killing fields, I will show how the Khmer popular religious system is instrumental in forging a memory of those who died under the Pol Pot regime. Democratic Kampuchea produced thousands of killing fields where corpses were simply abandoned. In other places like health centres, detention camps or places of execution, mass graves were dug nearby and corpses thrown $\mathrm{in}^{8}$. The district of Bakan contains many such places because the province of Pursat suffered very badly at that time. According to David Chandler "the worst conditions of

\footnotetext{
${ }^{6}$ Among the most important publications using different approaches are Adhémard Leclère (1899), Le Bouddhisme au Cambodge, Ernest Leroux Publish., Paris; François Bizot's four volumes of the series Recherche sur le Bouddhisme Khmer (1976-1989), Paris, Publications de l'Ecole Française d'Extrême-Orient; Olivier de Bernon (2000), 'Le rituel de la 'grande probation annuelle' des religieux du Cambodge (mahæparivæsakamma)', Bulletin de 1'Ecole Française d'Extrême-Orient, Vol. 87, №2, pp. 473-510; John Marston and Elizabeth Guthrie (eds.), Cambodian Buddhism, History and New Religious Movements (2004), University of Hawai'i Press, Honolulu; Ian Harris (2005), Cambodian Buddhism: History and Practice, University of Hawai'i Press, Honolulu.

${ }^{7}$ The most important contributions are those of Eveline Porée-Maspero's three volumes, Etude sur les Rites Agraires des Cambodgiens (1952-1964-1969), Mouton, Paris/The Hague; Choulean Ang has written numerous articles on many aspects of the religious popular beliefs. See in particular Choulean Ang (1986), Les Etres Surnaturels dans la Religion Populaire Khmère, CEDORECK, Paris.

${ }^{8}$ The 2008 survey of the Documentation Center of Cambodia indicates 19.521 mass graves throughout the 180.000 square kilometres of Cambodia.
} 
all were probably in dambon [Khmer Rouge district] 2 and 6 in Pursat ${ }^{9}$, where new people were made to carve villages out of malarial forest. In these zones, deaths from starvation, disease, and overwork were frequent, while CPK cadre suffered from regional purges in 1976 and 1978. They were replaced, here and in the northwest, by cadre brought in from the Southwestern Zone, the area controlled by Ta Mok [... ${ }^{110}$. Moreover, after the rebellion of the Eastern Zone cadres in 1978, thousands of people from Svay Rieng and Prey Veng were sent to Pursat and killed. Many of them wore blue scarves (krama) and some villagers I interviewed remembered the fear and pity they felt when they met those evacuees ${ }^{11}$. Nowadays, when an uninformed visitor rides his/her motorcycle through the sunny paddy fields with their typical sugar palms, the cool chamcar (cultivated fields) and the quiet villages, he/she cannot be aware that a few meters from the path, behind a tree, lies a well full of human bones or a field named "Svay Rieng" because hundreds of deportees from the Eastern provinces, including newborn babies and pregnant women, were slaughtered there one night in 1978.

Before returning to the village of Kompaeng Svay and its haunted rice fields, I will analyze two other forms of justice and memory set up at the international level with the United Nations-sponsored Khmer Rouge court, and at the national level with the state remembrance policy.

\footnotetext{
${ }^{9}$ My own field research takes place in former Khmer Rouge districts (dambon) 2 and 7.

${ }^{10}$ David P. Chandler (1991), The Tragedy of Cambodian History. Politics, War, and Revolution since 1945, Yale University Press, New Haven and London, p. 269. See also the detailed description of daily life in dombon 2 and 7 by Michael Vickery (1984), Cambodia: 1975-1982, South End Press, Boston, pp. 114-118.

${ }^{11}$ Ben Kiernan has analyzed the distribution of blue scarves to evacuees from the East as a step in their planned elimination. However, Steven Heder convincingly argues that the distribution was not planned in order to make the people from the East more recognizable, although he agrees with the fact that the Pol Pot regime, "inspired by a modernizing ideology with genocidal potentialities, realizes those potentialities through a set of genocidal practices". See Ben Kiernan (1996), The Pol Pot Regime. Race, Power, and Genocide in Cambodia under the Khmer Rouge, 1975-1979, Yale University Press, New Haven and London, pp. 392-416; Steven Heder (1997), 'Racism, Marxism, Labeling and Genocide in Ben Kiernan's The Pol Pot Regime', South East Asia Research, Vol. 5, N. 2, p. 101-53.
} 


\section{Misunderstanding and discrepancy surrounding the Khmer Rouge Court}

\section{The "Khmer Rouge Tribunal"}

The "Khmer Rouge Tribunal" was set up in 2007 when five of the prominent leaders of Democratic Kampuchea (among those who are still alive ${ }^{12}$ ) were arrested and held in preventive detention ${ }^{13}$. This raised once more issues of justice and memory, some thirty years after the fall of the Khmer Rouge regime. This was a significant step after ten years of negotiation between the Cambodian government and the United Nations regarding the creation of a mixed court ${ }^{14}$. As an outcome of these debates, the Extraordinary Chambers in the Courts of Cambodia (E.C.C.C.) were specially created for the trial and may "fit into [the] 'second generation' of international criminal justice mechanism" 15 which gives more importance to the law of the host country than the former ad hoc international tribunals in former Yugoslavia and Rwanda. Although the running of such a court is not an easy task, the first case was judged in May 2010 : Duch, chief of the biggest political prison where thousands of people were tortured and killed, was found guilty of crimes against humanity and sentenced to thirty-five years in prison ${ }^{16}$.

This Court will try at least four other leaders charged of crimes against humanity and/or war crimes perpetrated between April 1975 and January 1979. These crimes were perpetrated under the radical communist regime inspired by Mao, his radical entourage and his agrarian state doctrine. The Khmer Communists dreamt of achieving what they called a "super great leap forward" that would boost Cambodia to an economic and political level of

\footnotetext{
${ }^{12}$ Pol Pot, the so-called brother Number One died in 1998. Ta Mok and Ke Pauk also passed away in the 1990s and 2000 s.

${ }^{13}$ Namely, Ieng Sary, Ieng Thirith (Khieu Thirith), Kaing Kek Eav (alias Duch), Khieu Samphan and Nuon Chea.

${ }^{14}$ The two Cambodian prime ministers Hun Sen and Norodom Ranariddh asked for the help of the United Nations for the settlement of a tribunal in 1997. The law creating the Extraordinary chambers in the courts of Cambodia was adopted by the Cambodian Parliament in 2001 and was promulgated by the King in 2004. See David Boyle (2001), 'Une juridiction hybride chargée de juger les Khmers Rouges', Droits Fondamentaux, $\mathrm{N}^{\circ} 1$, pp. 213-227.

${ }_{15}$ John D. Ciorciari (2006), 'Introduction', in The Khmer Rouge Tribunal, in John D. Ciorciari (ed.), Documentation Center of Cambodia, Phnom Penh, p. 18.

16 The judges reduced the sentence by five years because he had been held illegally by the Cambodian government in the 1990s, and reduced it by a further eleven years for time already served behind bars.
} 
sophistication equivalent to that of the Angkor era (eighth to fifteenth century), when Cambodia was a powerful empire. This Utopia led to a totalitarian organization whose chiefs ordered the deportation of hundreds of thousands of people sent to work without compensation in the agricultural sector. The revolution sought to destroy family ties, religious practices, and the education and health systems, while trying to create new institutions like health centres and (in some cases) schools, but with little success. The policies of Democratic Kampuchea (DK) led to the deaths of at least one million seven hundred thousand people who were executed (the military of the Lon Nol regime were particularly targeted), starved, overworked or died of untreated diseases and other abuses, as well as internal purges among the Khmer Rouge cadres themselves. One million seven hundred thousand represented a quarter of the Cambodian population in 1975. Nowadays, one can still read advertisements in newspapers, on posters or via the Internet, written by survivors looking for their family members who disappeared over thirty years ago. In the Cambodian paddy-fields and bush, hundreds of thousands of human remains are still scattered or piled in mass graves, without having had a proper funeral. Many people still do not know where their loved ones died.

\section{Discrepancies}

At a time when the eyes of the world are focused on the trials of the Cambodian communist leaders in Phnom Penh, some journalists have reported that the Cambodians' opinion regarding this trial is not clear-cut. Some well informed urban people criticize the high cost of this United Nations-sponsored court while rural people feel no strong interest in this trial. Moreover, most of the genocide memorials built by the Cambodian government in the 1980s were no longer looked after in the 1990s and they have now disappeared or are in very poor condition. A few of them were repaired in the 2000s for various reasons related to tourism, pressures from the Cambodian diaspora and local political interest (described below). This seeming discrepancy between worldwide interest in the Khmer Rouge trial and the lack of interest expressed inside Cambodia itself has raised questions among Western observers. Some have written that the Cambodian attitude should be understood in reference to the Buddhist philosophy of detachment. Others have said that this is due to the attitude of some prominent Cambodian political leaders (including Prime Minister Hun Sen) who were themselves former Khmer Rouge cadres and wanted the past to be forgotten and witnesses to remain silent.

I woud argue that these explanations do not give a comprehensive picture of the many misunderstandings surrounding the Khmer Rouge Trial regarding post-genocide justice, 
compensation and bereavement. Indeed, all of these misunderstandings have occurred since 1975 due to discrepancies and gaps of various kinds between the actions and perceptions of various actors such as the United Nations and the Western countries, the Cambodian governments and their allies, and the Cambodian people, including the villagers (who represent more than seventy-five per cent of the Cambodian population). These gaps are related to the timing of the trial, the level of charges against the perpetrators, the perceptions of suffering and the construction of memories of the genocide. In particular, as we shall see, while the United Nations-sponsored trial was organized some thirty years after the genocide, other local systems of justice and remembrance had already been set up.

In what follows I will focus on the Cambodian peasants. Although they suffered greatly during the Khmer Rouge regime ${ }^{17}$, they have aroused little interest among journalists (apart from the villagers living in Northern Cambodia ruled by the former Khmer Rouge guerrilla, most of the information came from interviews with the Cambodian diaspora and the city dwellers) or among researchers. The latter have mostly conducted research on the power structure of Democratic Kampuchea while the process of the internalization of the Khmer Rouge terror has been described through biographies and autobiographies. Only a few examples of field work have dealt with the impact of the Pol Pot regime on the social life of the peasants and their own perception of the genocide and its aftermath ${ }^{18}$.

17 The Pol Pot regime had divided the population into two categories, the "old people" and the "new people" depending on when they joined the revolution. The "old people" who lived in areas under communist control prior to 17 April 1975 were generally better treated than the "new people" especially regarding punishments. Some interviewees in Pursat suffered seriously from hunger but were not mistreated. They sometimes even appreciated social justice and the improvement of agriculture through the construction of waterways (implicitly criticizing the current government which does not take care of the infrastructure). However, many other villagers saw their relatives dying from hunger, overwork, or execution.

${ }^{18}$ Kate G. Frieson (1993), 'Revolution and rural response in Cambodia: 1970-1975' in Ben Kiernan (ed.), Genocide and Democracy in Cambodia: the Khmer Rouge, the United Nations and the International Community, Yale University Southeast Asia Studies, Monograph series, New Haven, Conn., pp. 33-50; May Ebihara (1993), 'A Cambodian Village under the Khmer Rouge, 1975-1979', in Ben Kiernan (ed.) Genocide and Democracy in Cambodia., op. cit., pp. 51-63; May Ebihara (2002), 'Memories of the Pol Pot era in a Cambodian village' in Judy Ledgerwood (ed.), Cambodia Emerges from the Past: Eight Essays, Center for Southeast Asian Studies, Northern Illinois University, DeKalb, IL., pp.91-108; Ebihara May and Judy Ledgerwood (2002), 'Aftermaths of Genocide: Cambodian villagers' in Alexander Hinton (ed.), Annihilating Difference: The Anthropology of Genocide, University of California Press, Berkeley, pp. 272-291; Eve Monique Zucker (2006), 'Transcending time and terror: the re-emergence of bon dalien after Pol Pot and thirty years of civil war', Journal of Southeast 
As a Khmer-speaking anthropologist involved in research on Cambodians since 1986, I have gathered data in various circumstances showing that the Cambodians have not remained silent, unconcerned or reluctant to try the Khmer Rouge leaders, but have instead developed, decades before the trial, their own "relief device" from social suffering and their own sophisticated "memory device" interlinked with the traditional Khmer religious system. This has been working silently for thirty years now, far from the city and the journalists. In describing here a part of this "relief device", I do not mean that the "Khmer Rouge Court" is unnecessary because the Khmer people have created their own resiliency system. The work of the Court is an important part of the construction of international post-genocide justice in a globalized world. However, I suggest that the Tribunal has been used as a part of what Michel Foucault would have called the "biopolitics of international justice". In other words, many narratives of the Tribunal have focused on the "healing" of the victims as its most important role, as if post-genocide justice were foremost a matter of health. By doing so, the accounts given in many areas of the Tribunal have tended to impose an overall pattern of what social suffering should be and how it should be expressed and relieved, by using the idioms of "trauma" and "post-traumatic stress disorder" as their only models. The ideology underlying the overuse of the psychiatric scheme helps to reinforce the marginalization of small societies like Cambodia in the globalized world by producing a particular image of them: not only did the Cambodians slaughter each other during an "auto-genocide" 19 , not only did they suffer from mental illness caused by trauma but they also remained unconcerned and passive after the genocide. This ideological pattern in turn aims to make the proliferation of so-called humanitarian organizations in Cambodia acceptable by spreading the idea that Cambodians cannot help themselves or be treated as responsible citizens.

Asian Studies, Vol. 37, N³, pp. 527-546; Eve Monique Zucker (2008), 'In the absence of elders: chaos and moral order in the aftermath of the Khmer Rouge' in Alexandra Kent and David Chandler (eds.), People of Virtue: Reconfiguring Religion, Power and Moral Order in Cambodia Today, Nordic Institute of Asian Studies, Copenhagen, pp.195-212.

${ }^{19}$ See the criticism of the use of the word "auto-genocide" by Richard Rechtmann (2001), "Altérité suspecte et identité coupable dans la diaspora cambodgienne', in Jean-Christophe Attias et Esher Benbassa (eds.), La Haine de Soi: Difficiles Identités, Ed. Complexes, Brussels, pp. 173-188. 


\section{Taking care of the dead of the state memorials}

\section{The state remembrance policy}

Democratic Kampuchea was overthrown in January 1979 by its former Communist allies from Vietnam. Cambodia was then in chaos. The new Cambodian government set up under the supervision of the Vietnamese quickly made efforts to build up national justice and memory. Pol Pot and Ieng Sary were sentenced to death in absentia by the Revolutionary People's Court ${ }^{20}$ while people in the countryside were forbidden to take the law into their own hands by punishing some of the local Khmer Rouge cadres (but not all of them) who had been cruel. A museum was set up inside the main political detention camp (S-21) with the help of East European museography specialists. The new People's Republic of Kampuchea (PRK) also dealt with the numerous mass graves, killing fields and individual corpses scattered all over the country.

Local authorities were urged to put the human remains together and place them in boneyards built in each commune (khum). Villagers helped in picking skulls and "long bones"

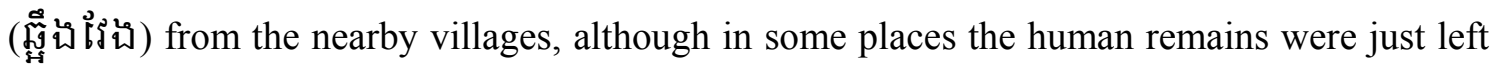
in a pile in the bush under a big tree or left in ponds or wells. These boneyards and memorials

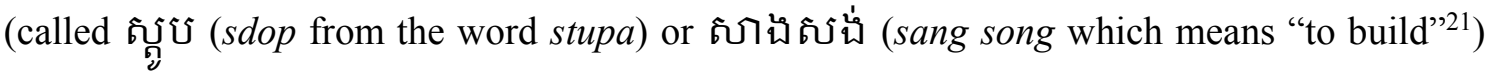
were more or less sophisticated depending on the amount of money available locally, since the country was then enduring extreme poverty. They were made of wood or bricks covered by a roof of palm leaves or tiles. More than eighty memorials were built in Cambodia in the 1980s according to the Documentation Centre of Cambodia. Officials of the Party who were appointed members of the newly created Committee of organization of national celebrations

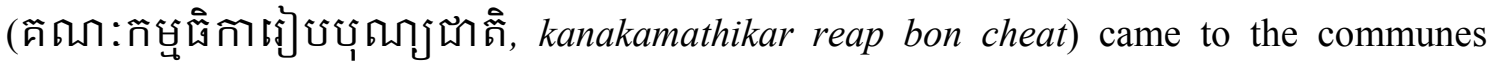

\footnotetext{
${ }^{20}$ Tribunal Populaire Révolutionnaire Siégeant à Phnom Penh pour le Jugement du Crime de Génocide Commis par la Clique Pol Pot-Ieng Sary. Documents (1990), Maison d'Edition en Langues Etrangères, Phnom Penh.

${ }^{21}$ It still remains unclear to me why the verb sang song is used in this context as a noun without the usual prefix $\operatorname{kar}(\tilde{ก} \delta)$.
} 
(khum) of Pursat and visited the killing sites. They helped in organizing the 7 January Liberation Day and the 20 May celebrations. The former was the anniversary of the overthrow of the Khmer Rouge regime while the latter was the so-called Day of Anger

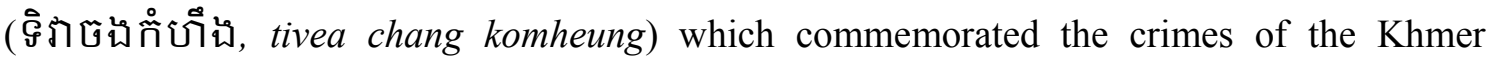
Rouge. Every year, an official ceremony was held in front of the memorials. Although Buddhism was scarcely tolerated in the 1980s, monks from the nearby monasteries were

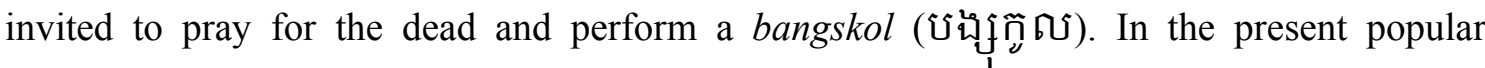
perception common in mainland South East Asian Theravadin countries ${ }^{22}$, this means that laymen make offerings to the monks who, in turn, by chanting special prayers, are able to send the merit obtained to the dead. The celebration was also organized for political and propaganda purposes: at that time, the Vietnamese protectorate over Cambodia was criticized inside as well as outside the country and the government made efforts to explain the presence of over 100,000 Vietnamese soldiers and political advisors by insisting on crimes committed by the "Pol Pot clique" and the danger they still represented if the survivors were not protected by the Vietnamese. The human remains then became the best proof of the genocide and therefore a symbol of the legitimacy of the newly-installed Vietnamese-backed government. In the province of Pursat for example, I was told that the authorities had sometimes "borrowed" the bones from village memorials in order to organize bigger ceremonies at the provincial level ${ }^{23}$.

Then, in the early 1990s, state memorials were gradually neglected by the officials and

\footnotetext{
22 On the different meanings of bangskol in non reformed and reformed mohanikay Cambodian sects, see François Bizot (1981), Le Don de Soi-même. Recherches sur le Bouddhisme Khmer III, Publications de l'Ecole Française d'Extrême-Orient, Paris.

${ }^{23}$ Rachel Hughes quotes a 1983 memo from the Ministry of Information and Culture urging provincial authorities to build at least one memorial in each province prior to the fifth anniversary of National Liberation Day, 1984. See Rachel Hughes (2006), Fielding genocide: post-1979 Cambodia and the geopolitics of memory, Phd. diss., University of Melbourne, p. 117. I agree with this author when she reckons that the memorials have played different roles - including that of organizing public mourning - and cannot be seen only in the negative manner of a pure strategic instrument of empowerment for the Cambodian People's Party. Moreover, Cambodian society is in the process of constructing a modern national identity and further analysis will be needed on the genocide as one of the founding events of this construction.
} 
abandoned in most communes, including the two I visited in Trapeang Chong and Snam Preah communes ${ }^{24}$. Nobody was interested any more in repairing and looking after these symbols of the genocide. This was concomitant with the collapse of the Cambodian Communist State and state-run facilities (such as ministries, hospitals, and schools) following the rise of political liberalization and the free-market economy. Moreover, these memorials had been set up at a particular time (cold war, Khmer Rouge guerrilla, isolation of Cambodia, flow of refugees) with ideological and strategic objectives which no longer existed after 1991, when the Peace Agreement was signed between the four Cambodian parties, followed by the establishment of the United Nations Transitional Authority in Cambodia ${ }^{25}$. As a former district deputy chief of Bakan told me when I asked him why the memorials were not looked after in the 1990s: "Government policies were changing and we did not know what the future would be like, so we sold the state land [including the collective land where the memorials were built]. Moreover, when Prince Sihanouk came back [in 1991], we were told that our government was making an agreement [with the opposition parties including the Khmer Rouge]. There were two opposite opinions on the subject of the memorials. The first one stated that it was important to keep the bones ( The second was that keeping the bones would bring back the war". As for the peasants' perceptions, these memorials were seen as state-sponsored commemoration devices and as such, they did not feel concerned by them. However, the celebration of the Day of Anger was still performed but it was given a new political colour, "downgraded" to the status of a partysponsored event that now bears the name of เตารตริ Tribute to the Spirits [of the dead of the Pol Pot regime]). In Pursat and elsewhere, the rituals

\footnotetext{
${ }^{24}$ Some memorials are still looked after for different reasons and by different organizations, all over the country. See Rachel Hughes (2005), 'Memory and sovereignty in post-1979 Cambodia: Choeung Ek and local genocide memorials' in Susan Cook (ed.), Genocide in Cambodia and Rwanda: New perspectives, Transaction Publishers, New Brunswick, NJ., pp. 257-280; Jean-Louis Margolin (2007), 'L'Histoire brouillée. Musées et mémoriaux du génocide cambodgien', Gradhiva. Musée du quai Branly, Paris, ํㅜ 5, pp. 85-95.

${ }^{25}$ Rachel Hughes rightly names this period a "suspended historicity" before the process of commemoration was resumed in the 2000s. See her PHd diss., op. cit.
} 
are performed on public premises such as schools.

\section{The villagers take over}

After the government stopped looking after the memorials, villagers began to take care of the dead kept in some of them. Let us listen to the account given by M. Sophon. He is a peasant in his forties, owning a house near a memorial of this kind (Kropeu Ro village, khum of Snam Preah).

"This land has long belonged to my family. I was ten years old when I was deported to Kravanh district by Pol Pot. My sister died at that time [M. Sophon also personally witnessed several murders]. I came back here soon after the Pol Pot regime ended. In 1979, there were a lot of mass graves with four or five corpses in each pit. The head of the sub-district (mekhum) asked us to put the skulls and other remains together and to erect a small building there, in order to keep them. He organized a bangskol celebration twice. At the beginning I was afraid here. Everybody was afraid. One day, the mekhum caught a thief and punished him by locking him inside the memorial with the skulls. The thief screamed the whole night and I can tell you he has never stolen again! One night, I saw a light like a ap $\left(\right.$ f $\left.^{-1} \tilde{U}^{26}\right)$ in the mango trees and the tamarind trees. Nobody dared to go out at night. But later on, the memorial gradually fell into ruins because nobody took care of it any more. And after a while, the ghosts (โஜ્นิษ, khmaoch) became harmless, unable to bother the living (literally "tasteless", ธับษ์, sap). So we were no longer afraid. Later on, I planted banana trees in the field of the memorial. But when I work in my field, I keep on digging up remains."

M. Sophon's narrative is representative of other stories I have heard from villagers living near mass graves. Many people saw ap-like lights in the night near the memorials and former killing fields and a young man even told me that his younger sister lost all her hair

\footnotetext{
${ }^{26}$ An ap is a female witch who belongs both to the natural and supernatural world. She goes out at night, her head and bowel floating low in the air and emitting a phosphorescent blue light. She is linked with bad death and human waste. See Choulean Ang, Les êtres surnaturels, op. cit., pp. 263-284.
} 
after having seen such a light ${ }^{27}$. The widespread fear of ghosts/corpses ${ }^{28}$ was due to the fact that most of the dead of the Pol Pot regime died a "bad death" without a proper funeral. Like in other South East Asian societies, people who commit suicide, are murdered, have fatal accidents or die during childbirth are perceived as "bad dead" (khmaoch tai hong,

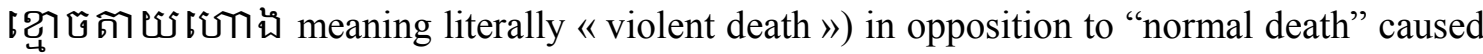
by old age and ordinary diseases (i.e. associated with natural aetiology). Shorter funeral rituals are usually performed and the risk exists that these dead would not follow the usual way of the sampāra but would transform into malevolent entities of various forms staying near the living. The victims of the Pol Pot regime potentially belong to this second category. However, the fear was not general as many people point out that they used to come across corpses during the Pol Pot regime and even sleep near them or among them in the forest. "Hungry people are afraid of nothing, they just think about eating and surviving", an old woman told me when I asked her if she was afraid of these ghosts. Some young people recall playing with the skulls of the dead in the bush when they were children in the early $1980 \mathrm{~s}$, when human remains scattered in fields were a familiar sight ${ }^{29}$. M. Sophon's interview suggests that after the trauma of the Khmer Rouge regime, people gradually became increasingly involved in making a living and rebuilding their lives. Rice fields and fruit trees were planted again over the mass graves, which symbolically meant that the life cycle was starting again. A former village chief told me that he created a new market near the Snam Preah memorial so as to prevent ghosts from bothering the living, because ghosts prefer remote, dark and uninhabited places (there is still no electricity or roads in much of the Cambodian countryside and in the 1980 s, there were only bicycles).

\footnotetext{
${ }^{27}$ The narrative of people losing their hair after encountering spirits, particularly priey ([6mes) which share some characteristics of the ap, is not uncommon. See Choulean Ang, Les êtres surnaturels, op. cit., p. 129, n. 309).

${ }^{28}$ In Khmer language, khmaoch ([Ö) interact with human beings. The dead are always liable to come in contact with the living hence the superimposition of the meanings of khmaoch.

${ }^{29}$ Another informant told me that these ghosts were too weak to be harmful because they had nothing to eat.
} 


\section{Family funeral rituals}

At the same time, hundreds of thousands of funeral rituals were performed by the families whose relatives had died during the Pol Pot regime. These dead were not the usual dead : their deaths were "bad" and collective and their corpses were abandoned in unknown places, away from home. Were the funeral rituals performed different from those usually used on more "normal" occasions? Usually the rituals performed during "normal death" begin with religious assistance to the person who has died by reminding him/her of the principle of impermanence and helping him/her to leave the material world ${ }^{30}$. These rituals were simplified in the early 1980s when Buddhism was scarcely tolerated by the PRK and when very few monks were ordained. The main element of change in the funeral rituals of people who died under Democratic Kampuchea regime was the impossibility of performing the

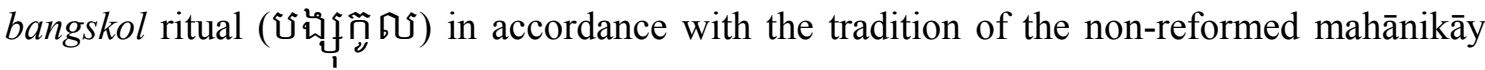
Buddhist rituals, which implies that the corpses or human remains are present ${ }^{31}$. However the practices of the reformed mahānikāy, also widespread in Cambodia in the 1980s, while using the same prayers, have a different meaning and do not involve the physical presence of the dead : the offering of a piece of clothing to the monks is simply perceived as producing merit which is sent along to the dead. So in many cases, the fact that the corpse was not recovered does not bear the same importance as in Vietnam where those who have "died in the street" can not benefit from the cult of the ancestors until the corpse is given back to the family ${ }^{32}$. Furthermore, some aspects of the treatment of the dead "without a corpse" are similar to those of the dead "with a corpse".

\footnotetext{
${ }^{30}$ See the description of these rituals in Adhémard Leclère (1907), La Crémation et les Rites Funéraires au Cambodge, Schneider, Hanoi, pp. 72-73; Evelyne Porée-Maspero et al., (1958), Cérémonies Privées des Cambodgiens, Editions de l'Institut Bouddhique, Phnom Penh, pp. 68-76; François Bizot (1981), Le Don de Soi-même, op. cit.

${ }^{31}$ Bangskol is originally the worthless fabric used to make the monks' habits according to the first of the thirteen ascetic rules. In the non reformed tradition, the corpse or the ashes are covered with the bangskol. The monks pull on the clothes while they are praying, symbolically appropriating an old fabric found on a corpse (as did the ascetics in early times). The ritual of the old mahanikay sect symbolizes self-sacrifice and re-birth, according to François Bizot's analysis. François Bizot, Le don de soi-même. op. cit.

${ }^{32}$ Heonik Kwon, op. cit., pp. 83-102.
} 
Firstly, data from my research in Pursat suggests that cremation, although generally performed, is not essential. In the monasteries, several graves whose owners are said to be "Khmer" and not only "of Chinese origin" 33 can be seen near the stupas containing the ashes. Even senior monks sometimes choose to be buried rather than cremated according to their "personal taste", as I was told in one such monastery where the abbot had ordered the building of an ornamented bier in a "cool place" on the riverside where his body was put after his death. Burials can also be temporary and furthermore, ashes are sometimes buried in the stupa. It is as if the Khmer ritual treatment of the dead needed to remain linked with the earth rather than fire. Indeed, the "abandonment [of the corpses] in the forest" (ka boh chaol knong

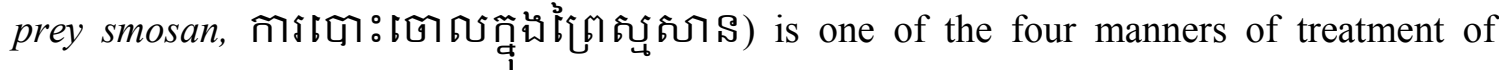
corpses prescribed by Theravada Buddhism, the current abbot of Koh Keav monastery told $\mathrm{me}^{34}$. Secondly, many aspects of the treatment of the "normal" dead are collective just like the state rituals in front of the memorials described above, and also the main Festival of the Dead described below. For example, monasteries often have a collective stupa. If not, individuals

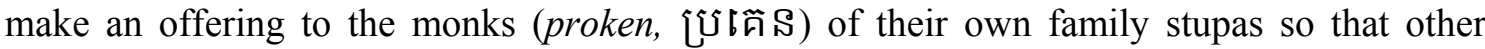
people can use them and bring their own family funeral urns.

The difference between the rituals for "good" and "bad" deaths is not great. In both

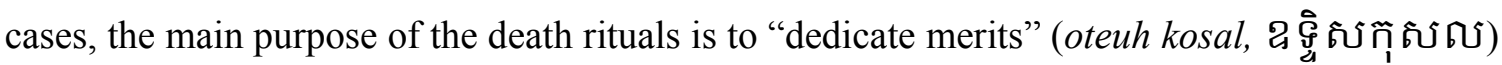
to the dead in order to make their future existence as good as possible. This is the case for the bangskol performed when death occurs as well as for other ceremonies known as pachay

\footnotetext{
${ }^{33}$ Jean Delvert in his classical monography, has written that the kind of funeral, cremation or burial, gives information on the Khmer or Chinese cultural badkground. See Jean Delvert (1994 [1rst publ. 1961]), Le paysan cambodgien, L'Harmattan, Paris, p. 26.

${ }^{34}$ The three other manners are cremation, burial, and drowning in the Ganges (not carried out in Cambodia). Offering of corpses to the birds was carried out until the beginning of the $20^{\text {th }}$ century. Abandonment of the corpse in the bush was described before the Pol Pot regime by François Bizot as a practice of the non reformed mahanikay sect. See Adhémard Leclère, La Crémation..., op. cit., pp. $72-73$ and François Bizot, Le Don de Soimême, p. 15.
} 


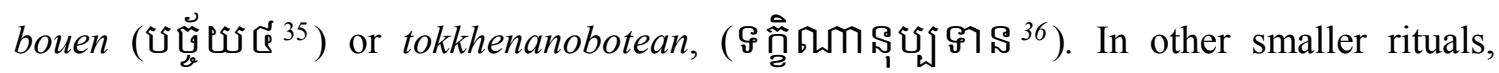
people who want to worship their dead whose bodies have not been found can make offerings to the monks while giving the dead person's name to the achar (lay specialist of the cult) so that he can send the merits to this person through his prayers.

When the annual festival of the dead was re-established in the early 1990s, it became easier to pay tribute to them. I myself witnessed a huge relief among the population in the days following the first festival, as if the atmosphere was suddenly lighter and quieter. This traditional festival is known in Khmer as the Gathering of the Riceballs festival (phchum ben, กู่บิธิณ were missing and had not received proper funerals because the phchum ben is essentially a collective ritual which aims at helping all the "souls" to reincarnate. This is the very meaning of the making of the riceballs (บิณֻ, ben, from Sanskrit pinda) by villagers over a two-week period in the monasteries during the lunar month of September-October (photrobot). The riceballs (ben) are less an offering of food than a back-up for reincarnation offered to the wandering souls. Ben therefore symbolize the human "shape" (§ॄ๊ One can also assume that during the phchum ben, calling the name of the dead leads to the combination of the "name and shape" (

${ }^{35}$ Pachay means the money offered to the monks (pali, paccayo). See Father Tandart (1935), Dictionnaire cambodgien-français, Albert Portail publish., Phnom Penh. This big private ceremony is organized for the dead father and mother as a mark of gratitude. Four kinds of offerings (hence the name pachay 4) must be made to the monks and "the organizer should not regret at any moment the huge amount of money spent", following an achar (lay specialist of rituals).

${ }^{36}$ Tokkhena means "alms". This is a less prestigious private ceremony which consists essentially of meals offered to the monks who can either bring the food to their monastery ( $18 \delta$ is ceremony is performed (

${ }^{37}$ It was named the Festival of the Dead during the French protectorate and this name is still used among Westerners.

${ }^{38}$ I am indebted to Choulean Ang who gave me a copy of his unpublished research presenting this analysis of Phchum ben. See also Commission des Moeurs et Coutumes du Cambodge (n.d.), Cérémonies des douze mois, Institut Bouddhique, Phnom Penh, p. 47-58. 
being.

One might think that the rituals performed and the efforts made to look ahead meant that the unknown dead of the mass graves, killing fields and memorials had been forgotten or at least kept at a distance from the living. This is true, but is not the end of the story, only its beginning. The Khmer system of mourning and memory is not based on a linear principle which would suppose that suffering and loss would be gradually lessened by the work of time and rituals of death. It is based on a circular principle that could be called "switch on/switch off". During a second phase, the dead burst forth again from time to time into the world of the living, especially via dreams. Let us continue listening to M. Sophon's experience.

"One night, five or six years ago [twenty-four or twenty-five years after the genocide], I dreamt of a man named Sok. He told me that he did not know where to go. He was a dead person from the memorial. So the next morning, with the help of a neighbour, I carried all the human remains from the memorial to another place near the railway behind my house. This was a good place to put the remains because the dead could then go whenever they wanted, towards the east or the west. They could go back to their native land (srok). So we burnt all the remains there. I lit three incense sticks and prayed for the dead, asking them to go back home. And since then, I make offerings of water, rice and food to them every year during the Gathering of the Riceballs Festival (phchum ben)."

The dead are still connected to the living via the dreams in which they can speak and ask the living to fulfil their needs. In M. Sophon's case, they asked for a funeral ritual to be performed. In other cases, they can "behave" like land spirits. When I interviewed people living around the mass graves about their relationship with these places, it became progressively clear to me that there were many similarities between these dead and the neak ta land guardian spirits. The similarities refer firstly to the relationship with the natural environment, secondly to the relationship with death, and thirdly to interactions with the living. I will discuss these three points now. 


\section{The dead of the mass graves and the land guardian spirits}

\section{The neak ta land guardian spirits}

Neak ta means literally "person-old male" or "person-grand-father" while in Pursat, they are usually called lok ta ("Mister grandfather" used as a term of address as well as a noun $\left.^{39}\right)$. They are often perceived as the founding couple of the village, who cleared the forest and built the first houses ${ }^{40}$. They are therefore perceived as ancestors and are sometimes

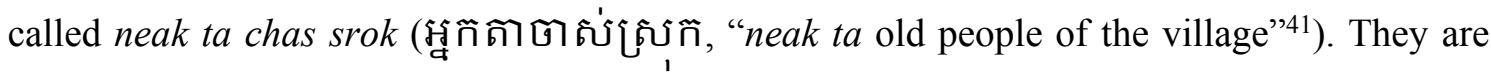
key elements of the Khmer popular religious system as spirits protecting and controlling the land and its inhabitants ${ }^{42}$ and they play an important role in structuring village social life and strengthening the peasant community ${ }^{43}$. In post-genocide society, where hundreds of thousands of people fled from Cambodia or were moved to other provinces or towns, worshipping neak ta can also maintain a link with the native village or territory (srok). Each neak ta is believed to be the protector and the controller of a specific piece of land which can be as small as a part of a village or a monastery or as large as a province. This is the case of Grandfather Khleang Mueng ${ }^{44}$ whose shrine is in the village where I worked. He is a powerful and well known neak ta protecting and controlling Western Cambodia and he is nowadays worshipped as far away as Long Beach, California ${ }^{45}$. The land guardian spirits communicate

\footnotetext{
${ }^{39}$ Lok ta is a common term of address for old men including monks.

${ }^{40}$ Referring to my own work in Pursat, I found that the female counterpart of the neak ta is sometimes implicit and somehow merged into the neak ta entity.

${ }^{41}$ Choulean Ang, Les êtres surnaturels..., op. cit., p. 205-206.

42 Alain Forest adopts a constructivist analysis of the neak ta by suggesting that common personal spirits can be upgraded to the status of neak ta only if the whole peasant's community acknowledge them as such. See Alain Forest (1992), Le culte des génies protecteurs au Cambodge, L'Harmattan, Paris, pp. 37-40.

${ }^{43}$ David Chandler suggests that the cult of the neak ta has also been instrumental in providing a sense of national unity. A royal-sponsored cult may have been established for the most important spirits, each controlling a part of the kingdom, as early as in the $9^{\text {th }}$ century and probably before. David Chandler (1976), 'Maps for the Ancestors: Sacralised Topography and Echoes of Angkor in two Cambodian Texts', Journal of the Siam Society, Vol. 64, $\mathrm{N}^{\circ} 2$, pp. 170-187.

${ }^{44}$ Khleang Mueng is a name of Thai origin which means "central pillar of the district".

${ }^{45}$ Teri Shaffer Yamada (2004), 'The spirit cult of Khleang Moeung in Long Beach, California', in John Marston and Elizabeth Guthrie (eds.), History, Buddhism, and New Religious Movements in Cambodia, University of Hawai'I Press, Honolulu, pp. 213-225.
} 
with the living through mediums called rup ("physical shape") or smeung rup (ถึํำนู่ิ) although not all of them have mediums. I found in Pursat that these spirits (or at least some of them) also communicate through the dreams of the living.

\section{Merging into the natural environment}

Neak ta are located in specific places, mainly in specific trees like Sterculia foetida

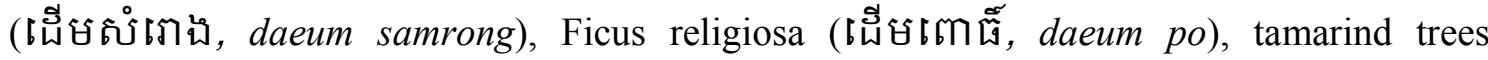

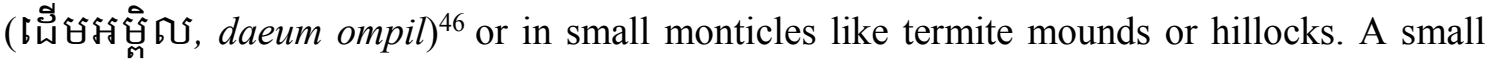
house is made for them resembling a human house. The object representing the neak ta (also called fî, rup, "physical shape”, like the human medium is) is very simple and unsophisticated and sometimes there is even no representation at all. In this case, the neak ta's house contains only offerings. When the physical shape exists, it is a piece of an old statue, or a raw stone, or a termite mound ${ }^{47}$. This clearly shows that the spirit is merged into the natural environment rather than simply staying in it ${ }^{48}$, just like the bodies of the victims of the Pol Pot regime. Indeed, the great majority of the corpses remain unidentified and have lost their individuality, at least in the local dwellers' perceptions ${ }^{49}$. They were heaped together in ponds, wells and earth in the forests and bush, and became part of the natural environment. They are often associated, just like the neak ta, with hillocks, big trees like daeum samrong

\footnotetext{
${ }^{46}$ Choulean Ang (Les êtres surnaturels, op. cit., p. 202) also mentions daeum slaeng (Strichnos nux vomica) and daeum chrey (Ficus Spp.).

${ }^{47}$ However in towns, new statues with human bodies and faces are progressively replacing the old altars. This indicates an evolution in the worship of the neak ta that I cannot discuss here.

${ }^{48}$ Paul Mus (1934), 'Cultes Indiens et Indigènes au Champa', Bulletin de l'Ecole Française d'Extrême-Orient, Vol. 33, $\mathrm{N}^{\circ} 1$, p. 374.

${ }^{49}$ Some well off families who have been able to locate the place where their parent died make offerings to the neighbouring monasteries. This is thus a middle-term ritual between the collective and anonymous treatment of the mass graves and the memorials, and individual funerals. During these ceremonies, the name of the dead

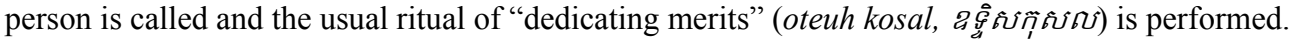


(เผี่ยิธ่์เาฝ้, Sterculia foetida), tamarind trees or termite mounds ${ }^{50}$. In the killing field of Don Am village (Tropeang Chong commune) which now looks like peaceful grassland, the corpses were gathered together by the villagers and put near a big white mango tree ${ }^{51}$. Termite mounds began to grow there some years later.

The dead of the mass graves behave as masters of the place, in the same way as the neak ta. They are "touchy" and "ill-tempered" and cannot stand a disrespectful attitude from the living walking through their places : using inappropriate words, behaving casually and taking natural resources without permission can bring punishment as bad as death to careless human beings. For instance, the powerful land spirit guardian Khleang Mueng is widely believed to have killed several Khmer Rouge soldiers who were cutting samrong trees near his shrine. In doing so, he showed his power. The power of the masters of the land can also be made visible through other appearances of animals like crocodiles, snakes or tigers, lights during the night, or supernatural events such as branches of trees moving by themselves from the roof of the shrine. Although I have never been informed until now that the dead of the mass graves could be as aggressive as Khleang Mueng, some of them are powerful enough to punish people who use their place without permission or behave badly. For example, in Don Am village, a female neighbour in her thirties (born just after the Pol Pot regime) experienced the anger of a dead person lying in a well where lots of corpses were thrown during the Democratic Kampuchea.

"Nobody dares to do anything in this place, like using or cutting down the trees. When I was a young girl, I once came here in order to pick some tamarind fruit. Suddenly, my foot slipped on the edge of the well and then a stone fell into it. The night following this event, I dreamt that a man wearing black shorts [she believes that this man was a Khmer Rouge soldier who was purged and thrown into the well ${ }^{52}$ ] was angry with me and criticized me for

\footnotetext{
${ }^{50}$ Until now I have not observed association with stones like in the case of the neak ta.

${ }^{51}$ Mango trees are not usually the shelters of the neak ta but I assume that there were no other trees around, so the villagers decided to choose this unusual mango tree (white and bigger than ordinary ones) as a "meeting point" for the corpses.

${ }^{52}$ Many Khmer Rouge cadres and soldiers were themselves killed in extensive purges targeting the "enemy".
} 
throwing a stone into the well. The stone, he said, crushed (ธันุ้ดั่, sangkot) the corpses in the hole. The next morning, I came back, offered incense sticks and begged forgiveness for my misbehaviour. I have never dreamt of this man again".

Energy is believed to emanate from the places where powerful neak ta dwell. Such places are said to be "powerful” (ஜำฝ้, khlang) and to be full of "energy" (ยาณธาริีี, mean boromey). The same energy radiates from some mass graves and killing fields. Boromey is derived from the pali word "pāram $\vec{\imath}$ ", which mean the ten Buddhist perfections leading to Nibbāna. François Bizot ${ }^{53}$ has convincingly drawn a genealogy from the initial Buddhist meaning to the Khmer popular meaning of “'strength', 'power', 'sacred energy' emanating from a cult artefact". Following the South East Asian Buddhist tradition, he states, the Buddha left behind Him His image and the ten pāramī and made them the protectors of His Learning for five thousand years. The meaning of boromey has thus evolved into the power emanating from the statues themselves (enhanced by sacred relics left inside them), identified with the power of the guardians of those statues, often assimilated with spirits like neak ta. My field work in Pursat showed me that boromey is perceived as a circulating energy present in some trees, stones, events, artefacts, people (especially of royal background), and spirits linked to special places. In particular, the trees housing the neak ta reinforce the power of the

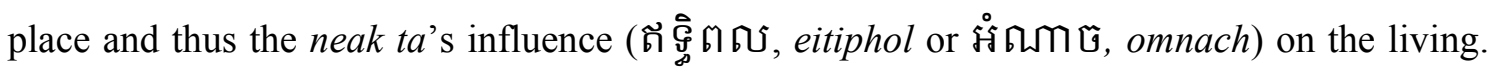
Cutting down trees near the spirits' shrines is dangerous not only because this act would offend the master of the place, but also because it lessens its spiritual power. For instance, Grandfather Khleang Mueng is perceived by many villagers as less powerful than before the Pol Pot regime because many big trees such as samrong trees have been cut down around his shrine. Similarly, the spiritual energy boromey emanates from some mass graves and is "composed" of trees, events (slaughters), the spirits of the dead, and possibly stones, as well

The Khmer Rouge cadres and soldiers wore black pyjamas.

${ }^{53}$ François Bizot (1994), 'La consécration des statues et le culte des morts', in François Bizot (ed.), Recherches Nouvelles sur le Cambodge, Publications de l'Ecole Française d'Extrême-Orient, Paris, p.116. 
as offerings. The boromey emanating from them depends on the characteristics of the natural environment and possibly on the events linked to the death itself ${ }^{54}$.

\section{Good and bad deaths}

In his illuminating essay on neak $t a$, the French researcher Alain Forest sees the neak ta as "un mort présent chez les vivants" 55 " (a dead person present in the world of the living 56 ). He puts forward the hypothesis that the Khmer pre-Buddhist perceptions of death - as far as it is possible to know them through myths and ethnographic data - evoke the dead person's trips back and forth from the island of the dead to the realm of the living. After a period of time spent on the island of the dead, resembling the Meru mount, the dead are reborn in their native locality (srok). Alain Forest argues that, the neak ta is a spirit which, for some reason, has not been transformed into the spirit of a dead person sent to the island of the dead, and therefore cannot be reborn. In this way, it is similar (but not identical) to those who have died a bad death, those who have committed suicide, been murdered, drowned, struck by lightning, or have died in childbirth. Those who have died a bad death are called "uncooked ghosts"

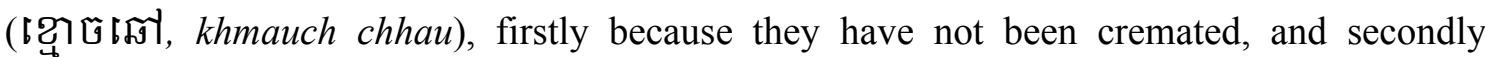
because they do not belong to the village anymore ("cooked" is opposed to "uncooked" as the village/civilization is opposed to the forest/savagery, as Claude Levi-Strauss has shown in his classic study). They are believed to be dangerous for the living. In the countryside, they are left in the forest or the cemetery ${ }^{57}$. Although not all neak ta have died a bad death ${ }^{58}$, this is the

\footnotetext{
${ }^{54}$ Not all the killing fields and the mass graves are perceived as "powerful". For example, in Andong Somboue village, the killing field is known as "the Svay Rieng rice field" because tens or hundreds (depending on the interviews) of people deported from the province of Svay Rieng were slaughtered there in 1978, including children and newborn babies, sometimes still alive near their mothers' bodies after the perpetrators left. Two or three children escaped and were adopted by the villagers. Apart from the name given to the place, there is apparently no remaining trace of the dreadful event. Nobody has witnessed any phenomenon suggesting a neak ta-like presence. But there were lights and ghosts in the night until some years ago. An old man told me that one night in 1992 or 1993, a villager saw all the ghosts walking in single file back to their native locality (srok).

${ }_{55}^{5}$ Alain Forest, Le culte des génies, op. cit., p. 113.

${ }^{56}$ A further piece of information is that the etymology of the modern Khmer word "grave" (萿s, phnor) is the old khmer word "monticle" (vnur) where the neak ta live. Choulean Ang, Les êtres surnaturels, op. cit., p. 202.

${ }^{57}$ Choulean Ang, Les êtres surnaturels, op. cit., pp. 102-103.

${ }^{58}$ One of the reasons of it is that not all the neak ta have been human beings before becoming land spirits.
} 
case of one of the most famous ones, Grandfather Khleang Mueng, who was a local major in King Ang Chan's army (sixteenth century). The Khmer army was fighting a stronger Siamese army in Pursat. Out of desperation, Khleang Mueng offered to commit suicide with his wife, his children and his troops in order to ask for the help of an army of ghosts. He did so and many Siamese soldiers died from diarrhoea and the army was defeated ${ }^{59}$. The fact that Khleang Mueng offered his life and died violently makes him particularly powerful as a neak ta. As an old keeper of the shrine puts it: "Grandfather Khleang Mueng is powerful because he chose to kill himself". In sum, the dead of the mass graves can easily be "elected" as neak ta due to their bad death in violent and terrifying circumstances. I will compare the data concerning Grandfather Khleang Mueng with some observations regarding the "future of the dead Pol Pot".

Pol Pot himself, who died in April 1998 in Northern Cambodia, shares some characteristics with neak ta. In a text entitled "The wandering souls of the victims of the Pol Potist Khmer Rouge" published in His Monthly Bulletin of Documentation ${ }^{60}$, the King-father Norodom Sihanouk writes angrily that "Pol Pot (who died quietly in his bed) has become, in his grave in Anlong Veng, a 'saint'. In front of this grave, his compatriots queue every day, lighting candles and incense sticks. Thus, the worshippers of Saint Pol Pot can win the lottery and other gambling games (in casinos or elsewhere). True [my translation from French]". Indeed, Pol Pot's grave has become a new place of pilgrimage for some Cambodians as well

\footnotetext{
59 This is the basic version that the villagers told me. There are other versions. See in particular Choulean Ang, Les êtres surnaturels, op. cit., pp. 206 sq; B.R. [sic] (1940), 'Folklore et Légendes du Cambodge. Le génie Khléang-Muoeung', Indochine, $\mathrm{N}^{\circ} 11$, p. 5-7 ; Sok Khin (1975), Chroniques royales du Cambodge, 1975, Thèse doctorat $3^{\mathrm{e}}$ cycle [PHd], Univ. de Paris V, p. 206-213 ; E. Porée-Maspero (1961), 'Traditions orales de Pursat et de Kampot', Artibus Asiae, N 24, p. 394-398 ; E. Porée-Maspero (1964), Etude sur les Rites Agraires.., vol. 2,

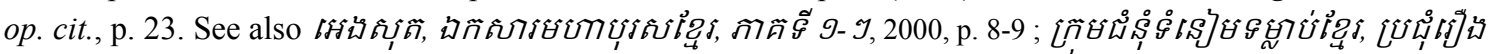

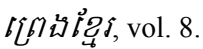

${ }^{60}$ The text was published in French: 'Les âmes errantes des victimes des Khmers rouges polpotiens', Bulletin Mensuel de Documentation, 25 July 2006. Quoted by Olivier de Bernon, 'Du manifeste à l'obscénité commerciale. Le traitement du souvenir des victimes des Khmers Rouges à Phnom Penh et dans les environs', in Higô no shi no kioku. Tairyô no shisha o meguru hyôshô no poritikusu [Collective death. Memory building and politics] (in Japanese), ed. Anne Bouchy and Masaru Ikezawa (Tôkyô: Akiyama shoten publisher).
} 
as an international tourist site supervised by the Ministry of Tourism ${ }^{61}$. The potential worship of one of the bloodiest dictators in world history appears strange and shocking at first glance, but it can be explained if we refer to the Cambodian popular religious world. In his lifetime, Pol Pot was a powerful man who could order the murder of whoever he wanted. This power remains after his death and it also associated with the place where he lived at the end of his life, and died. It is unclear if Pol Pot died of a heart attack (as the King-father writes in an article quoted above), committed suicide, or if he was murdered. In other words it is unclear if he died a "good" or a "bad" death. In any case, after his death, Pol Pot remains powerful, although this power can be used in a positive or a negative way, just like that of the neak ta. He is believed to be able to help the living who come and speak to him but I assume that, on the contrary, he can harm those who are not respectful toward the place where his ashes have rested since his cremation. My hypothesis is that the more powerful the individual during his life, the more violent and associated with violence his life and death, the more powerful he will become as a neak ta (if he does become one). This is consistent with other findings such as the performance of a royally sponsored human sacrifice to an important neak ta, Me Sar ("the White Mother"), at Ba Phnom (province of Prey Veng) as late as in $1877^{62}$. Another example of the power emanating from the offering of a person who has been violently killed

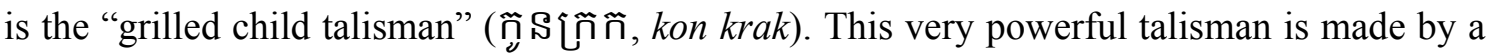
man whose wife is three or four months pregnant. The husband must disembowel his wife and take the foetus from her womb. He then grills the foetus. The talisman cannot work if the child has not been given to the husband by his wife before the murder. Usually the man deceives his wife by cuddling her while asking her if she agrees that the child is his. When she answers that the child is of course her husband's child, the murderer is ready to take the

\footnotetext{
${ }^{61}$ Timothy Dylan Wood (2006), 'Touring memories of the Khmer Rouge (Anlong Veng)', in Leakthina ChauPech Ollier and Tim Winter (eds.), Expressions of Cambodia: the politics of tradition, identity, and change, Routledge, London/New York, pp. 181-192.

${ }^{62}$ David P. Chandler (1972), 'Royally sponsored human sacrifices in nineteen-century Cambodia: the cult of neak ta me sar (Mahisasuramardini) at Ba Phnom', The Journal of the Siam Society, Vol. 62, N 2, pp. $209-922$.
} 
foetus out of the mother ${ }^{63}$.

\section{Intervening in the lives of the living}

Neak ta establish relationships with the living, through their human medium - either in an unplanned way or during annual festivals paying tribute to them - or through dreams. They ask the living to fulfil their needs for food, cigarettes, shelter, etc. They can also give information on the aetiology of diseases, or predict the future. As for the "Pol Pot dead", I have not been aware of any case of possession of a human being in Pursat until now ${ }^{64}$. Rather, I have listened to several stories of dreams in which the dead person asks the sleeper to fulfil his/her needs as in the case described above of M. Sophon and the dead Sok who wanted to be given a funeral ritual. In the following quite comical example told by a fifty year old woman, a dead person in a mass grave just wants... to watch a film on television.

"In 1992 [more than ten years after the genocide], I dreamt that a voice coming from the well [in Don Am village, where the bodies were piled up] told me: 'Please come and give a video projection! The winning lottery number is 21 '. The next day, I ran to buy a lottery ticket and won three million riels [around 750 dollars]. Then my husband and I built a small

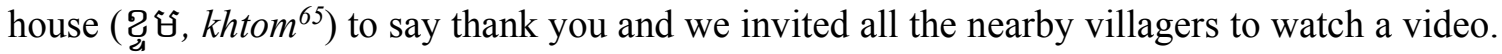
The video projector was installed near the mass grave as requested in the dream. Then, during the next Gathering of the Riceballs Festival (phchum ben), we made offerings to the dead of this mass grave. Later on, I dreamt once again of a voice coming from the well and revealing to me the winning lottery number. But later on, I never won again. [So she progressively lost interest in the mass grave and neglected to go and worship the place/the dead. Then the khtom fell into ruins]. But from time to time when I have a dream or fall sick, I always go to the well and offer incense sticks."

\footnotetext{
${ }^{63}$ Choulean Ang, Les êtres surnaturels, op. cit. pp. 157-158.

${ }^{64} \mathrm{I}$ have witnessed in other circumstances and places the informal possession of a neighbour by the spirit of a person who has just died of bad death.

${ }^{65} \mathrm{Khtom}$ is a temporary shelter built by peasants in the fields. It is also one of the names used for the neak ta's shrine.
} 
Stories about lottery numbers given in dreams are commonplace in Cambodia ${ }^{66}$ as well as in other Southeast Asian societies. This shows how neak ta (and the Pol Pot dead) are able to intervene in the daily lives of the Cambodian people, while karmic destiny is a far more abstract concept. Indeed, lottery games, like all forms of gambling, are perceived as being related to karma. Being lucky shows how good the individual's karma is and this widespread perception is instrumental in the success of gambling games in Cambodia.

Finally, neak ta and the dead of the mass graves are different from one point of view : neak ta are ambivalent invisible entities, who are able to punish the living but they are also keen to protect them. Many stories are told about people who were given useful information by neak ta during the Pol Pot regime so that they could survive. Until now, I have not heard that the mass graves/the dead protect the living. Instead, they behave as quick-tempered masters of the land.

\section{Conclusion}

In this article, I have analyzed the misunderstandings and discrepancies regarding the construction of justice and memories which occurred in the wake of the Khmer Rouge genocide. I have described in particular the sophisticated although unknown social device set up by the Cambodian peasants in order to express social suffering but also to give local meaning to the genocide. In the Khmer cultural system, the dead of the mass graves are not perceived as victims (as they are in the Tribunal) nor as proof of the Khmer Rouge savagery (as they are in the Cambodian People's Party's perceptions), neither are they ordinary dead. My hypothesis is that at least some of them are spirits in the process of becoming land guardian spirits. Massive bereavement has been incorporated into the popular religious framework, particularly into the cult of the land guardian spirits with whom the dead of the mass graves share many characteristics. This allows a specific relationship between the dead and the living and a specific memory of the genocide consisting of alternately forgetting and remembering. I have suggested this "switch on/switch off" device of memory to describe the

\footnotetext{
${ }^{66}$ Choulean Ang, Les êtres surnaturels, op. cit., p. 216.
} 
way in which the dead of the memorials were "forgotten" for a while when the living were busy rebuilding their lives after the mass destruction, by planting trees and setting up markets on the old killing fields, or when the dead person talking to a woman in her dreams stopped doing so after a while, becoming in return less worshipped until his shrine fell into ruins. These dead people, nonetheless, can burst into the daily lives of the living at any time. For years and years, from one generation to another, they will talk about the genocide and give it meaning in their own way - in a very different way from the kind of memory legitimized in Western societies. Via such "powerful places" as mass graves there is a possibility of the building and re-building of the meaning and memory of the genocide, in relation to the present. 